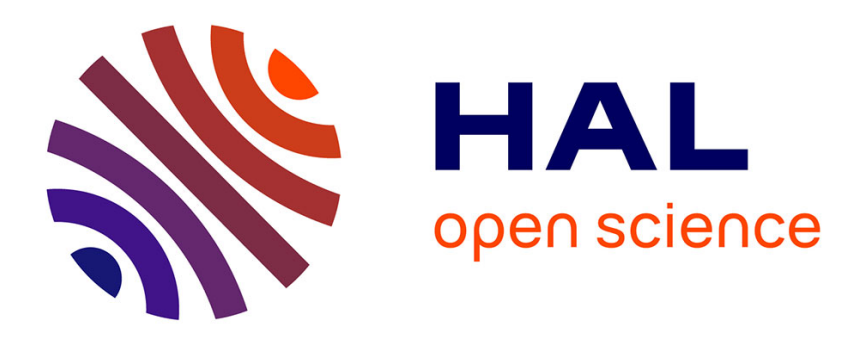

\title{
The phonology of Japanese /r/: a panchronic account Laurence Labrune
}

\section{To cite this version:}

Laurence Labrune. The phonology of Japanese /r/: a panchronic account. Journal of East Asian Linguistics, 2014, 23 (1), pp.1-25. halshs-00951955

\section{HAL Id: halshs-00951955 https://shs.hal.science/halshs-00951955}

Submitted on 26 Feb 2014

HAL is a multi-disciplinary open access archive for the deposit and dissemination of scientific research documents, whether they are published or not. The documents may come from teaching and research institutions in France or abroad, or from public or private research centers.
L'archive ouverte pluridisciplinaire HAL, est destinée au dépôt et à la diffusion de documents scientifiques de niveau recherche, publiés ou non, émanant des établissements d'enseignement et de recherche français ou étrangers, des laboratoires publics ou privés. 


\title{
The phonology of Japanese /r/: a panchronic account
}

\author{
Laurence LABRUNE \\ Université Bordeaux Montaigne \& CNRS UMR5263 (CLLE ERSS) \\ Laurence.labrune@u-bordeaux3.fr
}

Published: Journal of East Asian Linguistics 23:1, 2014, pp. 1-25

\begin{abstract}
The aim of this study is to understand how $/ \mathrm{r} /$ emerged and developed in ProtoJapanese, and how the conditions of its emergence shed light on its present phonological behavior. The paper first offers a review of the phonetic, phonological and morphophonological characteristics of $/ \mathrm{r} /$ in Japanese, through examination of a large array of empirical evidence. The picture that emerges is that of an unmarked, phonologically empty segment, confirming a number of previous studies, in particular that by Mester and Ito (1989).

I argue that /r/ primarily developed in Japanese as a default, epenthetic consonant in the intervocalic position within the morphological domain of a stem and its affixes, through an «Emergence of the Unmarked» mechanism before becoming a fully contrastive phoneme later on by virtue of a phonologization process. A formal account of this proposal within the framework of Optimality Theory is offered. It is shown that the phonological content of $/ \mathrm{r} /$ is acquired due to the application of well-formedness constraints (ONSET, ALIGN, MAXIO, DEPIO) as well as that of two sets of markedness constraints (FEATURAL AGREEMENT and HARMONy SCALE), which ensure that the null input is mapped to the least marked output in terms of phonological features.
\end{abstract}

Keywords:

Japanese, phonology, liquids, /r/, OT 


\section{Introduction ${ }^{1}$}

$/ \mathrm{r} /$ in Japanese stands out as a segment exhibiting many idiosyncracies, which make it unique in the phonological system of the language. This paper explores the special nature and status of $/ \mathrm{r} /$ in Japanese from a panchronic perspective, and aims at providing a principled account of its numerous special properties, including (among many others) initial prohibition, high frequency, and complementary distribution with zero. The main claim of this research is that the phonological characteristics of the rhotic in Modern Japanese can be understood through the way in which it emerged in the history of the language. I will argue that /r/ primarily developed in Proto-Japanese as a default, epenthetic consonant in intervocalic position within the morphological domain of a stem and its affixes by virtue of an « Emergence of the Unmarked » mechanism, and that the conditions of its development bear on its present-day characteristics.

The paper is organized as follows: section 2 reviews the empirical phonetic, phonological, and morpho-phonological data characterizing / $\mathrm{r}$ / in Japanese at different historical states of the language, which lead to its interpretation as unmarked. Section 3 attempts to provide a theoretical account of /r/'s special nature within the framework of Optimality Theory, developing the main claim of this paper, namely, that /r/ originally developed in Proto-Japanese in the context of a zero onset surrounded by two vowels. A conclusion is offered in Section 4.

\section{The characteristics of /r/ in Japanese}

We shall first review the set of characteristics of $/ \mathrm{r} /$ in Japanese, which include the following: phonetic variability, remarkably high frequency, complementary distribution with zero, phonotactic restrictions, role in the morphology, instability, phonological inertness and transparency, as well as functional equivalence of $-r \mathrm{~V}$ suffixes with reduplication. Except for section 2.1 - which deals with the phonetic aspects of $/ \mathrm{r} / \mathrm{-}$ and although the data will sometimes come from the modern language, the discussion below

1 Throughout this paper, the Japanese examples have been transcribed according to the Kunrei system, except for long vowels which are transcribed as $a a, i i, u u, e e$, and $o o$. For the presentation of the Japanese reference materials cited in the bibliography, the Hepburn system has been adopted. The symbol > denotes diachronic evolution, whereas / indicates synchronic alternation. Translation of the examples is given in double quotes 
will be mostly centered on Old Japanese (OJ, $8^{\text {th }}-14^{\text {th }}$ centuries), and more specifically on the indigenous Yamato component of the language. However, most of the characteristics reported below are still valid for Modern Japanese (MJ). Following the Japanese traditional linguistic terminology, the term Yamato is used to refer to what can be considered the native component of the lexicon, including mimetic words, and excluding items borrowed from foreign languages such as Chinese or Indo-European languages from around the $5^{\text {th }}$ century onwards.

\subsection{Phonetic realizations}

There is only one liquid phoneme in Japanese. Both historical and dialectal data indicate that there is no reason to doubt that this has been so since the times of the most ancient documents $\left(7-10^{\text {th }}\right.$ century) which provide the earliest detailed information on the Japanese phonological system.

The voiced apico-alveolar tap $[r]$ is generally assumed to be the prototypical realization of the liquid consonant in contemporary Japanese. According to Matsuno (1971), [ $]$ should be considered the neutral realization of the rhotic in the language, because its articulation is central compared to other variants. However, /r/ displays a large number of social, geographical or combinatory variants. Outside of [r], the following phonetic (social or regional) realizations are widely attested: [1], [l], [r], [r: $]$, $[\mathrm{d}],[\mathrm{r}],[\mathrm{b}]$.

The apico-alveolar lateral [1] is a common variant, frequent before palatalized vowels (rya, ryu, ryo) and in young women's speech (Ohnishi 1987, Tsuzuki \& Lee 1992). Retroflex [l] is also encountered under the same conditions. The short and long apical trills, [r] and [r:] are socially marked variants, characteristic of the popular speech of males from the Tokyo region. The higher the number of trills, the more sociallymarked the rhotic will be. The voiced alveolar stop [d] is a combinatory variant which is frequent word-initially in certain dialects, or in children's speech. It can also occur wordinternally. The retroflex $[\mathrm{r}]$ might be encountered initially before $/ \mathrm{u} /$, or intervocally in sequences such as /ere/, /ara/, /uru/, /oro/ (Tsuzuki \& Lee 1992). The fricative voiced

(“translation”). Glosses appear in simple quotes ('gloss'). 
lateral [b] is a combinatory variant occurring before the high vowels /i/ and /u/. Taken together with its other characteristics, this wide range of phonetic realizations is suggestive of the unmarked status of $/ \mathrm{r} /$.

Phonetically, /r/ is also the shortest of all Japanese consonants (Sagisaka and Tohkura, 1984, Kurematsu, 1997). In addition, note that whereas the phonetic quality of $/ \mathrm{r} /$ is frequently influenced by the surrounding vowels, $/ \mathrm{r} /$ itself does not seem to have any significant phonetic influence on the neighboring segments.

\subsection{Distribution and frequency facts}

Let us now examine what constitutes, in our view, the most important issue regarding /r/ in Japanese; the relation which, we claim, exists, between: i) /r/'s distributional gaps; ii) its overwhelming frequency in the language; iii) the fact that it is more likely to occur in the final mora of words; iv) the fact that it stands in complementary distribution with the zero consonant (empty onset). We consider that these properties are interrelated and proceed from a single cause. Any analysis of $/ r /$ in Japanese should be able to account for this state of affairs.

\subsubsection{Word-initial prohibition}

$/ \mathrm{r} /$ does not occur at the beginning of Yamato lexical words (free morphemes) ${ }^{2}$.

Note that it nevertheless occurs at the beginning of Yamato grammatical words (nominal or verbal affixes, bound morphemes) and at the beginning of non-Yamato lexical words (Sino-Japanese or Western borrowings). ${ }^{3}$

2 The absence of $/ \mathrm{r} /$ at the beginning of Yamato free words is sometimes taken as a proof that Japanese belongs to the Altaic family (Fujioka, 1908, and subsequent researchers). However, while it is true that Altaic languages do not have r-initial words, they are not the only languages in the world which present such a characteristic. Indeed, languages which lack /r/ at the beginning of lexical words are quite widespread (Labrune, in preparation).

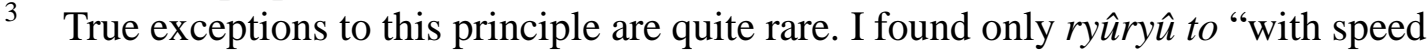
and force", rerorero "grumbling" or "incoherently", rorirori "restless", rin (rinrin, riin, ririin) 'ringing sound', runrun "in good spirit". All are mimetics. Rerorero and rorirori are the only ones with ancient attestation (rerorero is cited by the Iwanami Dictionary of Old Japanese [Iwanami Kogo Jiten], and rorirori appears in the Japanese Portuguese Dictionary [Vocabolario da lingoa de Iapam com a declaraçaõ em Portugues] compiled by Jesuit Missionaries of the Society of Jesus in 1603-1604). It is particularly significant 
It is frequently assumed that in human languages root morphemes exhibit more marked inventory of segments than do affixes and content morphemes (Beckman 1999:52, 183, McCarthy \& Prince, 1994, 1995). The positional asymmetry exhibited by Japanese /r/ may be taken as a clue in favor of its special status, an issue to which we shall return in section 3 .

\subsubsection{Frequency}

Although $/ \mathrm{r} /$ is absent at the beginning of Yamato lexical words, it is paradoxically the most frequent of all consonants in the word internal position in two and three-mora Yamato nouns, whereas it is the least frequent of all word-initially (Kokuritsu Kokugo Kenkyûjo 1984:25, Irie 1996).

\subsubsection{Distribution within stems}

$/ \mathrm{r} /$ is more likely to occur towards the right edge of Yamato stems. Consider the following data, taken from Kuginuki (1982), and based on a corpus of all the Yamato stems of early Old Japanese (between the $8^{\text {th }}$ and $11^{\text {th }}$ centuries).

to observe that rerorero and rorirori are exceptional in two respects: first because they begin with $/ \mathrm{r}$, second because they violate a strong phonotactic constraint, which is that identical consonants cannot occur twice in a mimetic root (Hamano, 1998:41-42, Schourup \& Tamori, 1992:120). I believe that the fact that exceptions to this second principle involve precisely $/ \mathrm{r} /$ and no other consonant can be interpreted as an additional proof that $/ r$ / is phonologically transparent, which explain why, unlike other consonants, it can be repeated. Other words which could appear as exceptional are reko «this », rutsubo «melting pot» or risu «squirrel ». Reko is based on the moraic inversion of kore «this », rutsubo either results from the loss of an original initial vowel $(<i r u$ tsubo), or from the hybrid compound ro-tsubo where ro is a Sino-Japanese morpheme, and risu is said to be a Sino-Japanese word, or to have evolved from kuri-suki '(the one who) likes chestnuts'. I thank Mark Irwin for providing me with some of these etymologies. 
Table 1. /rV/ moras in Old Japanese non-verbal stems. ${ }^{4}$

\begin{tabular}{|l|l|l|l|l|l|}
\hline & $1^{\text {st }}$ mora & $2^{\text {nd }}$ mora & $3^{\text {rd }}$ mora & $4^{\text {th }}$ mora & Total \\
\hline $\mathrm{ra}$ & $4(4)$ & $64(44)$ & $61(57)$ & $5(5)$ & $134(110)$ \\
\hline $\mathrm{ri}$ & $1(1)$ & $35(30)$ & $23(23)$ & $4(4)$ & $63(58)$ \\
\hline $\mathrm{ru}$ & & $26(17)$ & $10(9)$ & & $36(26)$ \\
\hline $\mathrm{re}$ & $1(1)$ & $20(19)$ & $7(7)$ & $1(1)$ & $29(28)$ \\
\hline $\mathrm{ro}_{1}$ & & $5(4)$ & $2(2)$ & $1(1)$ & $8(7)$ \\
\hline $\mathrm{ro}_{2}$ & $2(2)$ & $20(13)$ & $17(15)$ & $3(3)$ & $42(33)$ \\
\hline $\mathrm{Total}$ & $8(8)$ & $170(127)$ & $120(113)$ & $14(14)$ & $312(262=84 \%)$ \\
\hline
\end{tabular}

The first figure in each cell of table 1 indicates the number of $/ \mathrm{rV} /$ occurring as a given mora of non-verbal stems, i.e all word categories except verbs and auxiliaries, including the possible suffixes which may begin with $/ r /$. The figures in parentheses give the number of $/ \mathrm{rV} /$ occurring as the last mora of the stem. So, for instance, the figures 26 (17) on the "ru" line / " $2^{\text {nd }}$ mora" column indicates that we have 26 words containing $r u$ as their second mora (as in yoru "night" or sirusi "sign"), 17 of these words having it as their final mora (yoru "night", haru "spring", etc.). No stem exceeds four moras (longer forms are compound or suffixed words).

Table 2./rV/ moras in Old Japanese verb and auxiliary stems.

4 Archaic Japanese (before the end of the $9^{\text {th }}$ century) had two phonemically distinct $r o$ moras, labeled $\mathrm{ro}_{1}$ and $\mathrm{ro}_{2}$, which merged before 1000 to a single $/ \mathrm{ro} / \mathrm{mora}$. The vowels $i$ and $e$ were also involved in a similar type of opposition, with contrasting $\mathrm{C} i_{1}-\mathrm{Ci}_{2}$, and $\mathrm{C} e_{1}-\mathrm{C} e_{2}$ moras, but after /r/ only the $o_{1}-o_{2}$ opposition is attested. The actual phonetic and phonological difference between $\mathrm{CV}_{1}$ and $\mathrm{CV}_{2}$ moras remains controversial, see Martin (1987), Shibatani (1990: 131-139) or Miyake (2003) for a comparison of existing theories on this issues. 


\begin{tabular}{|l|l|l|l|l|}
\hline & $1^{\text {st }}$ mora & $2^{\text {nd }}$ mora & $3^{\text {rd }}$ mora & Total \\
\hline $\mathrm{ra}$ & $3(3)$ & $39(34)$ & $12(11)$ & $54(48)$ \\
\hline $\mathrm{ri}$ & & $2(1)$ & & $2(1)$ \\
\hline $\mathrm{ru}$ & & $7(7)$ & & $7(7)$ \\
\hline $\mathrm{re}$ & & $1(1)$ & & $1(1)$ \\
\hline $\mathrm{ro}{ }_{1}$ & & & $1(1)$ & $1(1)$ \\
\hline $\mathrm{ro}_{2}$ & & $11(9)$ & $6(5)$ & $17(14)$ \\
\hline $\mathrm{Total}$ & $3(3)$ & $60(52)$ & $19(17)$ & $82(72=88 \%)$ \\
\hline
\end{tabular}

Table 2 provides the same type of information for verb and auxiliary stems. Here, "stem" is to be understood as the part of the verb or auxiliary which stands before the $\mathrm{C} u$ or $-\mathrm{C} i$ ending of Old Japanese verbs, which undergoes inflection. Accordingly, the figures 39 (34) on the first line indicate that we have 39 verb or auxiliary stems such as kara-su "to dry" or uraya-mu "to envy" which have $r a$ as their second mora, with 34 of these having it as their stem final mora, like kara-su "to dry".

The data in tables 1 and 2 show that $84 \%$ of the $r \mathrm{~V}$ moras contained in OJ Yamato stems occur in the last mora of the stem. This proportion gets even higher, to $88 \%$, if one takes into account the most frequent ending of verbs and auxiliaries, which is $-r u$.

As we shall see below in more detail, Kuginuki (1982) argues that such a distributional pattern makes sense if one supposes that $/ r /$ emerged relatively late in the history of Japanese.

\subsubsection{Complementary distribution with zero (empty onset)}

In OJ, /r/ stands in complementary distribution with the zero consonant in noncompound words. The zero consonant corresponds to the lack of a phonetically audible initial consonant at the beginning of a mora, so that moras which phonetically begin with a vowel are considered to begin phonemically with a zero consonant. This empty initial can be filled by a light glottal stop in MJ. The zero consonant was widely recognized as a structural element by leading phonologists such as Hattori (1960), Wenck (1966) or McCawley (1968), who transcribe it as $/ 2 /$ or $l^{2} /$. 
It is a well-known fact that sequences of two adjacent vowels do not occur in OJ within a stem. ${ }^{5}$ Zero consonants, denoted as /'/ hereafter, are licit only at the beginning of non-compound words, that is to say precisely where $/ \mathrm{r} /$ is forbidden, so /'/ and $/ \mathrm{r} /$ stand in complementary distribution. ${ }^{6}$

Another fact deserving special consideration is that /'/ happens to be the most frequent type of onset in the word initial position: words beginning with a zero consonant represent between 20 and $25 \%$ of the Yamato lexicon (Kokuritsu Kokugo Kenkyûjo, 1984: 25, Sakakura, 1966, Labrune, 2012:99-100). This just parallels the frequency and distribution of / $/ \mathrm{r}$ which, as seen above, is the most frequent, or one of the most frequent of all, in intervocalic position. The correlation pattern between /// and $/ \mathrm{r} /$ can thus be summarized as in the chart below:

Chart 1. Pattern of distribution and frequency of $/ \prime /$ and $/ \mathrm{r} /$ in OJ (Yamato words)

\begin{tabular}{|c|c|c|c|}
\hline \multirow{2}{*}{} & \multicolumn{2}{|c|}{ Distribution } & Frequency \\
\cline { 2 - 3 } & $\#_{-}$ & V_V & \\
\hline$/ /$ & yes & no & $\begin{array}{c}\text { most frequent type of onset } \\
\text { word-initially }\end{array}$ \\
\hline$/ \mathrm{r} /$ & no & yes & $\begin{array}{c}\text { most frequent type of onset } \\
\text { word-internally }\end{array}$ \\
\hline
\end{tabular}

There is thus an apparent paradox in the distribution of /r/: although it does not occur word-initially in Yamato lexical words, it is remarkably frequent in other

5 In MJ the zero consonant can appear word-medially in Yamato lexemes, but this is due to a relatively recent evolution in the language. Modern $V^{\prime} \mathrm{V}$ sequences in noncompound words result from borrowing or from the loss of a consonant, as in kakite > kaite "write and...", or kowe > koe "voice".

6 Of course, complementary distribution does not automatically imply phonemic alternation or allophony. This expression simply aims at characterizing the distributional pattern of two segments which are phonetically different at the surface level. For instance although [h] and [y] stand in complementary distribution in English, they are not assumed to represent the same phonemic unit. However, as we shall see in the following pages, there exists a number of additional facts in Japanese which arguably lead to the interpretation of $/ \mathrm{r} /$ as the default filler of an empty position in the 
positions, i.e. in the medial position of Yamato lexical words. Moreover, /r/ is also extremely frequent at the beginning of several derivational or inflectional suffixes such as -ra (OJ, MJ) 'plural', 'directional', -ra / -ro (OJ) 'adverbial', -raka (OJ, MJ) 'adjectival ending', -raku (OJ) 'nominalizer', -ru (OJ) 'passive', 'potential', -ri (OJ, $\mathrm{MJ})$ 'adverbial', -ri (OJ) 'aspectual auxiliary', -re (OJ, MJ) 'deictic', -reru (OJ) 'passive, potential, honorific', -ro (OJ, MJ) 'imperative', -ro (OJ) 'particle (of obscure function)', etc. ${ }^{7}$

\subsection{Co-occurrence restrictions}

In OJ, /r/ never co-occurs with itself in a single stem, that is, there can be only one $/ \mathrm{r} /$ per stem. This restriction is especially remarkable in verbs. Whereas $-r u$ is the most frequent verbal ending in OJ according toYoshida $(1976: 87,101)$, it is not attested after roots which already contain an /r/ (Kuginuki 1982). Thus, while kaheru (<*kaperu), inoru, tonakaru, musaboru are well-formed and attested OJ verbs, forms with more than one /r/ are impossible and are indeed unattested but for one exception: hiroru ( < *piroru) "to spread, to widen".Verbal stems which already contain an /r/ end with any other kind of $\mathrm{C} u$ ending, so we find, for instance, uruhu (<*urupu) "to moisten", hiraku $(<*$ piraku $)$ "to open" or irasu "to lend", in place of *ururu, *hiraru or *iraru. ${ }^{8}$

The same type of co-occurrence restriction is also operative in OJ nouns and other parts of speech, to the exception of mimetics. Although there exists a tendency for other consonants to undergo co-occurrence restrictions based on total identity or place homorganicity in Yamato and mimetic roots (Kawahara, Hajime and Kiyoshi 2006, Hamano 1998: 41-42), they do not seem to be as strict as they are for $/ r /$. We thus find

intervocalic context.

7 The complementary distribution between the zero initial and [r] in Japanese is reminiscent of what occurs between English [ə] and [r]. The proposal that [ə] and [r] are surface reflexes of an underlying zero has actually been made for RP English by Giegerich (1999). A similar analysis has been proposed for several varieties of Dutch (van Oostendorp, 2001, Humbert, 1996 cited by van Oostendorp, 2001). All the segments involved here in Japanese, Dutch and English are arguably placeless at the phonetic or phonological level (see also footnote 19).

8 This constraint is not totally preserved in MJ (cf. oriru "to get down", ireru "to insert"), but even in the modern language, most verbs containing two occurrences of /r/ are compounds involving two stems, or are derived by addition of the suffix -eru which 
verbs such as kaku "to write", momu "to rub", nihohu (<*nipopu) "to smell”.

\subsection{Instability}

$/ \mathrm{r} /$ is the most unstable of all Japanese consonants, both diachronically and synchronically. Throughout the history of Japanese, $r \mathrm{~V}$ moras have frequently undergone syncope (de aru > da 'copula', karite > kate "provisions"; see also Kishida, 1984, for additional examples), unexpected paragoge (kabu > kabura "turnip", sippo / sippori "tail" [dialectal] ; see Labrune, 1998 for more examples).

\subsection{Phonological inertness}

A number of facts suggest that the phonological behavior of $/ \mathrm{r} /$ is that of a phonologically inert, transparent consonant, lacking phonological content. First, /r/ fails to undergo palatalization in the mimetic stratum. Second, it cannot be geminated. Third, unlike most other consonants, $/ \mathrm{r} /$ is never the cause of an assimilation process in Japanese. A fourth, additional process which we will consider in this section is /r/s phonological transparency in Ryukyuan, allowing coalescence of two non-adjacent vowels.

\subsubsection{Resistance to palatalization}

According to Hamano (1998), /r/ cannot undergo palatalization in mimetic forms (the data are from MJ, but the phenomenon is also true of $\mathrm{OJ}$ ).

In mimetics, palatalization is correlated with the semantic value of 'childishness' or 'excessive energy'. It normally occurs on the rightmost coronal consonant of a bimoraic root (1a). If the rightmost consonant is not a coronal, then the initial consonant will undergo palatalization, whatever its place of articulation (1b).

The liquid / $\mathrm{r} /$ behaves in an exceptional manner here because it cannot be palatalized when it occurs in the second mora, so that noronoro (1c) does not yield *noryonoryo, but nyoronyoro. Moreover, the presence of $/ \mathrm{r} /$ in the root does not block the palatalization of a non-coronal in the first mora, as we see in kyorokyoro. So /r/ actually behaves like a non-coronal with regards to this palatalization process.

is an innovation of the pre-modern language. 
(1)

a.

$\begin{array}{llll}\text { kasakasa kasyakasya } & \text { *kyasakyasa } & \text { 'dry objects scratching each other' } \\ \text { dosadosa dosyadosya } & \text { *dyosadyosa } & \text { 'something falling heavily' } \\ \text { b. } & & \\ \text { pokopoko pyokopyoko } & \text { *pokyopokyo } & \text { 'hopping around' } \\ \text { zabuzabu zyabuzyabu } & \text { *zabyuzabyu } & \text { 'splashing' } \\ \text { c. } & & \\ \text { noronoro nyoronyoro } & \text { *noryonoryo } & \text { "wriggly and curving movement" } \\ \text { korokoro kyorokyoro } & \text { *koryokoryo } & \text { "looking around restlessly" }\end{array}$

Note that palatalized /r/'s can be encountered in lexical strata other than mimetics, especially in the Sino-Japanese and foreign strata, so that /ryV/ is not an impossible sequence in Japanese. However, the difference between mimetic palatalization and nonmimetic palatalization results from the fact that in mimetics, palatalization is a "featuresized morpheme" (Mester \& Ito, 1989) which can be productively attached to a root under the conditions stated above.

/r/'s resistance to palatalization in mimetics has led Mester and Ito (1989) to the claim that $/ \mathrm{r} /$ is underspecified for [coronal] and that it is actually the unmarked sonorant of the system. ${ }^{9}$

\subsubsection{Resistance to gemination}

The second process to which $/ \mathrm{r} /$ is transparent in Japanese mimetics, but also in other strata of the lexicon, is consonant gemination as occurring in -ri suffixed forms, as reported by Mester \& Ito (1989, citing a p. c. by Poser). When the second consonant of a

$9 \quad$ A number of studies have criticized this analysis. Schourup \& Tamori (1992) argue that the non-occurrence of palatalization with $/ \mathrm{r} /$ in mimetics is best explained by articulatory difficulty. Kurisu (2009), while recognizing the marked character of palatalized rhotics cross-linguistically, claims that the resistance of Japanese /r/ to palatalization must be accounted for in terms of feature compatibility, so that underspecification does not need to be invoked. However, one can object that articulatory or feature compatibility factors alone cannot account for the many other properties of $/ \mathrm{r} /$ in Japanese. 
mimetic root is a voiceless consonant, suffixation of the adverbial ending -ri causes the second consonant of the root to undergo total gemination in case it is a voiceless obstruent (2a), or partial gemination (i.e. prenasalization) in case it is a voiced obstruent or a sonorant (2b). However, in case the consonant in question is $/ \mathrm{r} /$, neither gemination nor prenasalization can normally occur $(2 \mathrm{c})$.

\begin{tabular}{|c|c|c|}
\hline yapa & yappari & "after all" \\
\hline bata & battari & "with a bang" \\
\hline kaki & kakkiri & "exactly" \\
\hline goso & gossori & "entirely" \\
\hline \multicolumn{3}{|c|}{ b. $\mathrm{C} 2=[+$ voiced $]->$ prenasalisation } \\
\hline gena & gennari & "to satiety" \\
\hline simi & sinmiri & "intimately" \\
\hline boya & bon'yari & "absentmindedly" \\
\hline yawa & yanwari & "gently" \\
\hline koga & kongari & "to be nicely brown" \\
\hline$m a z i$ & manziri & "sleepless" \\
\hline \multicolumn{3}{|c|}{ c. $\mathrm{C} 2=/ \mathrm{r} / \quad \rightarrow$ nothing happens } \\
\hline koro & korori & $? *$ korrori $^{?} *$ konrori \\
\hline
\end{tabular}

Fully geminated /r/'s are also unattested outside of the mimetic lexicon in the Yamato and Sino-Japanese strata, and they are only marginally reported in Western borrowings or in some recent mimetic derivatives (Schourup \& Tamori, 1992:137). As for the moraic nasal /N/ + /r/ sequence, it does occur in Sino-Japanese and in Western borrowings, for instance in on'inron "phonology", a Sino-Japanese word, or onrii "only", a borrowing from English. However, in such cases, it represents a recent development and is to be phonologically analyzed as a combination of two distinct segments rather than the result of a prenasalization process in the strict sense. According to Mester and Ito (1989), total gemination of $/ \mathrm{r} /$ is impossible because it violates the Nasal Coda Condition, requiring all voiced sonorant codas to be nasal. Partial gemination is impossible because / $\mathrm{r} /$ is underspecified, and thus has no distinguishable 
parts available for separate linkage.

\subsubsection{Assimilations}

Whereas $/ \mathrm{r} /$ is frequently a target for assimilation, it is itself never the source of an assimilation. Numerous examples such as wakaranai (MJ) / wakannai (MJ) "understand + Negation", sakari-na $(\mathrm{OJ})>$ sakanna $(\mathrm{MJ})$ "flourishing", or tori-te $(\mathrm{OJ})>$ totte $(\mathrm{MJ})$ "take and...", where $/ \mathrm{rV} /$ is assimilated to a neighboring segment - resulting in total gemination -, can be reported, but there are no examples where a neighboring segment is assimilated to $/ \mathrm{r} /$ (see also the remark at the end of section 2.1 above). Such phonological inertness, or neutrality, can be argued to follow from /r/'s emptiness at the phonological level. $/ \mathrm{r} /$ is never the source for assimilation because there is simply nothing to assimilate in its phonological structure.

\subsubsection{Vowel coalescence across $/ \mathbf{r} /$}

In some dialects of the Ryukyuan linguistic family, coalescence of vowels over an intervening /r/ or /h/ is reported by Lawrence (2000), as in guru-han > goro-hon "fast" or pataki-ha > patake-he "to the field". Lawrence also mentions the fact that in the Nakizin dialect, mimetics containing the mid vowels /e/ and /o/ in a light syllable are only attested in roots with a medial /r/ followed by a heavy syllable containing /e/ and /o/, as in gerengeren or zoroozoroo. The vowels /e/ and /o/ appearing in the initial light syllable can therefore be accounted for only by positing a spreading of the second syllable vowel features over /r/. Within a feature geometrical analysis, such facts suggest that $/ \mathrm{r} /$, like the laryngeal $/ \mathrm{h} /$, lacks a supra-laryngeal node, thus allowing for the vowel features to freely coalesce across it. We take this phenomenon as an additional piece of evidence in favor of the structural emptiness and unmarkedness of $/ \mathrm{r} /$.

\section{2 /r/ and epenthesis}

\subsubsection{Role in the verbal morphology}

/r/ also plays an important role in the morphology of Japanese. It is crucially involved in the verbal inflection. MJ verbs can be divided into two classes: those containing a consonant-final stem, to which vowel-initial suffixes attach, and those with a vowel-final stem, to which consonant-initial suffixes attach, as the following data 
illustrate:

(3) Verbal inflection of C-final and V-final stems (MJ)

$\begin{array}{lll} & \text { C-final stem } & \text { V-final stem } \\ & \text { "scatter" } & \text { "see" } \\ \text { negative (irrealis) } & \text { mak-anai } & \text { mi-nai } \\ \text { adverbial } & \text { mak-i } & \text { mi } \\ \text { past } & \text { mai-ta }(<\text { maki-ta) } & \text { mi-ta } \\ \text { conclusive } & \text { mak-u } & \text { mi-ru } \\ \text { hypothetic (realis) } & \text { mak-eba } & \text { mi-reba } \\ \text { imperative } & \text { mak-e } & \text { mi-ro } \\ \text { passive } & \text { mak-areru } & \text { mi-rareru }\end{array}$

Before vowel-initial endings $(-u,-a n a i,-e b a$, etc. $)$, no consonant surfaces in the case of a consonant-final stem, contrary to what happens after a vowel-final base. According to de Chene (1985) and Mester \& Ito (1989), consonant-stem suffixes are basic, and initial /r/ in vocalic-stem suffixes is epenthetic. What is significant here is that the surfacing consonant is precisely $/ \mathrm{r} /$.

Interestingly, the default, epenthetic nature of $/ r /$ in the inflection system of Japanese verbs is becoming even more conspicuous in contemporary Japanese. In informal casual language, there exists a productive process by which a new verb can be coined out of a bimoraic or trimoraic base generally resulting from the truncation of a longer Sino-Japanese, Western or even Yamato word, to which the -ru verbal ending is added. We thus find kopiru "to copy" from kopii, makuru "to eat at McDonald's" from makku donarudo, jikoru "to have an accident", from jiko (SJ) "accident", etc. Consider the paradigm of takuru "to take a taxi" in (4), derived from the base takusii "taxi", which has been truncated to taku before receiving the -ru verbal ending.

(4) Verbal inflection of newly coined verbs (MJ)

"to take a taxi"

negative (irrealis) takur-anai

adverbial takur-i

past taku-tta $(<$ taku-ri-ta $)$ 


$\begin{array}{ll}\text { conclusive } & \text { takur-u } \\ \text { hypothetic (realis) } & \text { takur-eba } \\ \text { imperative } & \text { takur-e } \\ \text { passive } & \text { takur-areru }\end{array}$

As the comparison with maku and miru above will reveal, takuru follows the consonant-final inflection pattern, like maku, in spite of the fact that the final consonant of its base is a non-etymological /r/, like that of miru. In this case, the default /r/ has been generalized to all the forms of the paradigm, but the verb follows the consonantfinal conjugation pattern, an interesting case of morphological syncretism.

The verbal morphology of OJ provides similar types of evidence for analyzing /r/ as an epenthetic consonant. OJ had eight distinct verb classes, which have been arranged from left to right in table 3 on the basis of the number of their inflectional forms containing an /r/ in the ending which can be analyzed as suffixal (indicated in bold). Space does not allow us to enter into the details of the formation of these paradigms, a topic which has been much studied and debated both in Japan and in the West, ${ }^{10}$ but a glance at table 3 is enough to reveal the secondary, and thus presumably epenthetic, nature of the $r$ element in the rightmost six classes. Note that the quadrigrade and monograde classes are the two classes which have finally established as the two main inflectional patterns of MJ, as consonant-final and vowel-final classes respectively, having absorbed all the other types, except the K-irregular (kuru "to come") and Sirregular (suru "to do") classes which still subsist as irregular nowadays.

Table 3. Verbal paradigms of ninth-century Japanese $\mathrm{e}^{11}$

\begin{tabular}{|l|l|l|l|l|l|l|l|l|}
\hline & $\begin{array}{l}\text { R- } \\
\text { irregular }\end{array}$ & $\begin{array}{l}\text { Quadri- } \\
\text { grade }\end{array}$ & $\begin{array}{l}\text { N- } \\
\text { irregular }\end{array}$ & $\begin{array}{l}\text { K- } \\
\text { irregular }\end{array}$ & $\begin{array}{l}\text { S- } \\
\text { irregular }\end{array}$ & $\begin{array}{l}\text { Upper } \\
\text { bigrade }\end{array}$ & $\begin{array}{l}\text { Lower } \\
\text { bigrade }\end{array}$ & $\begin{array}{l}\text { Upper } \\
\text { monograd } \\
\text { en }\end{array}$ \\
\hline
\end{tabular}

10 See Ohno (1953), Sakakura (1966), Unger (1977), Yamaguchi (1985), Labrune (1996), Whitman (2008), Frellesvig (2008), among others.

$11 \mathrm{i}_{1}-\mathrm{i}_{2}, \mathrm{e}_{1}-\mathrm{e}_{2}$, and $\mathrm{o}_{1}-\mathrm{o}_{2}$ represent the distinction between two pairs of contrasting vowels (or moras) which have later merged to /i/, /e/ and /o/, see footnote 4 . 


\begin{tabular}{|c|c|c|c|c|c|c|c|c|}
\hline irrealis & ara- & maka- & sina- & $\mathrm{ko}_{2-}$ & se- & $\mathrm{oki}_{2-}$ & tuke $_{2^{-}}$ & mi- \\
\hline adverbial & ari & maki & sini & ki & si & $\mathrm{oki}_{2}$ & tuke $_{2}$ & $\mathrm{mi}$ \\
\hline conclusive & ari & maku & sinu & $\mathrm{ku}$ & su & oku & tuku & miru \\
\hline Adnominal & aru & maku & sinuru & kuru & suru & okuru & tukuru & miru \\
\hline realis & are & make $_{2}$ & sinure & kure & sure & okure & tukure & mire \\
\hline $\begin{array}{l}\text { Imperative } \\
\text { (Eastern } \\
\text { dialects) }\end{array}$ & & & & & $\mathrm{serO}_{2}$ & $\mathrm{oki}_{2} \mathrm{rO}_{2}$ & tuke $_{2} \mathbf{r O}_{2}$ & $\operatorname{miro}_{2}$ \\
\hline $\begin{array}{l}\text { Imperative } \\
\text { (Western } \\
\text { dialects) }\end{array}$ & are & make & sine & $\mathrm{ko}_{2}$ & $\mathrm{se}<\mathrm{SO}_{2}$ & $\mathrm{oki}_{2} \mathrm{yO}_{2}$ & tuke $_{2} \mathrm{yo}_{2}$ & $\operatorname{miyo}_{2}$ \\
\hline $\begin{array}{l}\text { Root } \\
\text { (Ohno, } \\
1953 \text { ) }\end{array}$ & *ar & $*_{\text {mak }}$ & $* \sin$ & $* \mathrm{kV}$ & $* s \mathrm{~V}$ & ${ }^{*} \mathrm{O}_{2} \mathrm{ko}_{2}$ & $*$ tuka & $* \mathrm{mi}$ \\
\hline gloss & be & scatter & die & come & do & arise & put & see \\
\hline
\end{tabular}

\subsubsection{First mora reduplication in $\mathrm{OJ}$}

According to Unger (1976:32), there was a productive process in early Japanese whereby the first mora of a verb root was doubled to form a new root with extended meaning, as in tuke- "attach" / tutuke- "continue", yam- "get sick" / yayam- "be troubled". Unger adds to the list wogam- "bow" / worogam- "revere", utape "appeal" / urutape- 'id.', name- "line up" / narabe- 'id.' , and $i$ - "mint, cast" / ir- "scorch". He then argues that exact reduplication of an $r$ beginning initial syllable should be reconstructed for these forms, i.e. *rogam- / *rorogam-, *rutape- / *rurutape-, *rabe- / *rarabe-, *ri/*riri.

According to him, /r/ later changed to zero before $/ \mathrm{i} /$, to $/ \mathrm{w} /$ before $/ \mathrm{o} / \mathrm{and} / \mathrm{u} /$, and to /n/ before /a/ word-initially. As a result of these rules, no OJ words begins with /r/. However, I claim that an analysis exactly opposite to Unger's proves to be more persuasive. First, I propose that the pair name-/ narabe- does not belong to the pattern under discussion, and be left apart (even in Unger's analysis, it is not clear why $/ \mathrm{r}$ / would change to $/ \mathrm{n} /$ before /a/ rather than to zero). Following Unger, I consider that worogam-, urutape- and ir- were derived through reduplication of the initial mora, but I posit instead that the original roots were *ogam-. *utape-, and *ir(i) (and not *rogam-, 
* rutape- and *rir $(i))$. Reduplication of the initial vowel in each form produced a sequence of two onsetless prosodic units (*oogam-, *uutape-, *iir-). In order to break the hiatus, /r/ was inserted after the first vowel, yielding *orogam-, *urutape-, and * $\operatorname{ir}(i)$-. The /r/ appearing in the reduplicant is therefore best analyzed as an intrusive, epenthetic segment.

Note that what Unger transcribes as worogam- phonemically corresponds to /orogam-/ (and even more precisely to $* / \mathrm{oro}_{2} \mathrm{gam}-/$, see footnote 4 above). According to a tradition dating back to the $13^{\text {th }}$ century, /o/ preceded by an empty onset has been transcribed with the letter を belonging to the w- column in the Japanese kana script, i.e. wo in Roman transcription, but there is no evidence that a labio-velar approximant ever occurred before the vowel in this position. Consequently, the root for "to bow" is phonologically *ogam-, with an onsetless initial prosodic unit, and not *wogam-.

\subsection{Functional equivalence with reduplication}

A final piece of morphological evidence in support of the unmarked status of Japanese /r/ can be invoked. As claimed by Labrune (1998), there exists in Japanese a morpho-lexical class of words ending with a $r+$ vowel suffix, which share the same type of linguistic values as reduplicated words, as baka-ra-sii / baka-baka-sii "foolish", toro-ro / toro-toro "yam", ware-ra / ware-ware "we", aka-ra (OJ) / aka-aka "reddish", etc. (unless otherwise specified, all examples are MJ). Examples involving partial reduplication, such as simi-mi (OJ) / simi-zimi / simi-ra (OJ) "fully" are also attested. It can be argued that such a functional correspondence between reduplication and $-r \mathrm{~V}$ augmentation reflects some ancient morphological process which involved some kind of iconic lengthening by means of unmarked segmental material. Reduplication, which copies segmental material from the base, appears as an unmarked lexical means to lengthen a base, whereas $-r \mathrm{~V}$ suffixation (where $\mathrm{V}$ is either a vowel copied from the base, either a default segment) can be analyzed as some unmarked segmental means to lengthen the base. The choice of /r/ to express such iconic lengthening, in parallel with reduplication, can be taken as evidence for the unmarked status of the rhotic in the phonological system of the language, and as a case of emergence of the unmarked. The status of /r/ in the cases discussed in Labrune (1998) is thus comparable to the status of other unmarked segments involved in partial reduplication or reduplication with fixed 
segmentism, for example /2/in Makassarese as described by McCarthy \& Prince (1994).

\section{Accounting for the phonological nature of $/ r /$ in Japanese}

On the basis of the evidence reviewed in section 2, the proposal that I would like to present is that /r/ originally developed in Proto-Japanese as a default, epenthetic consonant in the intervocalic position within the morphological domain of a stem and its derivational or inflectional affixes.

\section{1./r/ as an unmarked consonant}

In a well-known paper dealing with palatal prosody in Japanese mimetics in relation to feature predictability and underspecification, Mester and Ito (1989) claim that $/ \mathrm{r} /$ is the unmarked sonorant of Japanese, that it is underspecified for the feature Coronal, and that, in a feature-geometric representation, "the underspecified $r$ is nothing but a root node with internal major class specifications".

Two other studies investigating the internal nature of $/ r /$ in Japanese converge with Mester and Ito's insight for considering that $/ \mathrm{r} /$ is to be analyzed as an underspecified or relatively unmarked consonant at some level of representation. Labrune (1997) claims that $/ \mathrm{r} /$ is totally unspecified underlyingly and that it consists solely of an empty root node. Working within the model of Element Theory, Nasukawa and Backley (2011) propose that $/ r /$ should be represented by the single element ĐIĐ, which represents frontness in vowels and coronality in consonants. Segments containing a single element, they argue, are inherently weak.

The present paper will go one step further and argue that $/ \mathrm{r} /$ is totally featureless at the abstract level, even for the major class features, because all the information contained in its phonological representation is predictable. Although the analysis presented below focuses on the diachronic development of $/ \mathrm{r} /$ at the Proto-Japanese stage, my basic assumption is that /r/'s present idiosyncratic properties trace back to the circumstances of its diachronic development.

The range of facts reviewed in section 2 provides rich and varied evidence that Japanese $/ \mathrm{r} /$ is phonologically unmarked. Take, for instance, the variability of its phonetic realizations (2.1). This arguably results from the fact that some features are not fully specified at the phonological level, thus allowing for a non-distinctive, optional 
surface variation. Features such as [ \pm continuant], [ \pm lateral], [ \pm retroflex] are supposedly acquired at a later stage of the derivation, depending on sociolinguistic or contextual factors. Notice that all the features characterizing /r/ at the surface level appear as relatively unmarked: [+sonorant], [-nasal] and [+voiced] are unmarked in an intervocalic environment, whereas [coronal] can be seen as the unmarked place of articulation (Paradis \& Prunet, 1991).

High frequency (2.2.2), too, can be taken as a clue to the relative unmarkedness of a segment (Greenberg, 1966). Concerning /r/'s instability (2.4) as well as its phonological inertness, we assume that the range of phenomena involved provides direct evidence for /r/'s lack of intrinsic phonological substance.

Recall also that, as already noted, two exceptions to the dissimilation principle which forbids identical consonants to co-occur in a mimetic root involve precisely $/ \mathrm{r} /$, in rerorero and rorirori (see footnote 3 ). Such examples are probably more than anecdotal exceptions: they are significant because they constitute one more illustration of the fact that / $\mathrm{r} /$ behaves as a transparent, invisible segment. The OCP normally applying in mimetics fails to detect the succession of the same consonant in the case of $/ \mathrm{r} /$, because $/ \mathrm{r} /$ is empty in phonological content. ${ }^{12}$

The behavior of $/ \mathrm{r} /$ in the phonetics, phonology and morpho-phonology of Japanese is thus characteristic of what any theory of phonology would recognize as an unmarked, default segment.

\section{$2.2 / r /$ as a default epenthetic consonant}

Our interpretation of /r/'s idiosyncratic behavior is that diachronically, /r/ emerged

12 As pointed out by a reviewer, this seems to be inconsistent with the fact that two occurrences of $/ \mathrm{r} /$ are forbidden in Yamato words, especially in verb stems, as discussed in section 2.3. This is true. However, the situation of mimetics and verbs is not quite identical. One should keep in mind that the impossibility to have two /r/'s in mimetics and in verb stems does not proceed from the same cause (or constraint): in mimetics, it is not licit for any consonant to occur more than once within a root, whereas in verbs, it is not licit for / $\mathrm{r} /$ only to occur more than once. Another difference between mimetics such as rori-rori and verb stems such as the ill-formed verb *iraru is that the two $/ \mathrm{r} / \mathrm{s}$ occur within the same root in rori-rori (the root is rori) but not in *iraru. A morphological boundary exists between ira- and the - ru ending. This being said, this issue undoubtedly requires further investigation, which I leave to future research. 
as the result from the filling of an intervocalic empty position with unmarked features at the level of a non-compound word (a stem and its affixes). In other words, /r/ can be viewed as the phonologization of an empty onset created in the course of derivation or inflection.

The most direct evidence for this claim has been presented in 2.6. and 2.7. above, where we saw that /r/ appears as the default epenthetic consonant in a number of derivational patterns. Remember that in Yamato Japanese, /r/ always occurs in the V_V context (2.2). In a procedural, serialist model of phonology, one would consider that the features characterizing / $r$ / have been acquired, first, through propagation of neighboring features by means of assimilation. /r/ acquires its voicedness, its non-nasality, and its sonorancy because it is surrounded by two voiced, non-nasal, sonorant segments (i. e. vowels). When neighboring segments cannot provide/r/ with adequate melodic specification, more specifically, when they cannot provide $/ \mathrm{r} /$ with a place of articulation (which is actually always the case, since / $\mathrm{r} /$ only occurs in an intervocalic context, and vowel and consonant places of articulation are, we assume, substantially different), the featural content of $/ r /$ results from general or universal unmarkedness requirements. So $/ \mathrm{r} /$ is a coronal, because coronal is the unmarked place of articulation for consonants.

\section{3. /r/ as a consonant of (relatively) recent development}

As mentioned in 2.2.3 above, Kuginuki (1982), in an attempt to account for the fact that $/ \mathrm{r} /$ is more likely to occur towards the end of words, has proposed the idea that /r/ developed relatively late in the history of Japanese. According to Kuginuki, /r/ did not exist in the primitive language. His hypothesis is that $/ \mathrm{r} /$ was originally added to the phonemic inventory in order to increase the distinctive power of words, which were mostly one or two-mora long in Pre-Archaic Japanese. Japanese being a suffixing language, these newly added $r$-moras were likely to occur at the end of words. This would explain why /r/ does not occur word-initially, that it is most frequent as the final mora of stems, and that it normally occurs only once in a word.

We will follow Kuginuki's basic insight that /r/ appeared relatively late in the history of the Japanese language. But our analysis goes one step beyond Kuginuki's, because we assume that there exists a connection between /r/'s late development, the fact that it stands in complementary distribution with /'/ in OJ, and its unmarkedness. 
Its late development explains why, in contradiction with what would be assumed to be characteristic of a marked segment, rather than that of an unmarked and transparent one, $/ \mathrm{r} /$ tends to occur only once in OJ non-compound words, and is subject to positional restrictions. ${ }^{13}$ This presumably follows from the conjunction of three independent facts: first, /r/ appeared late in the inventory; second, Japanese is a suffixing language; third, Japanese words rarely contain more than one or two suffixes.

\subsection{A constraint-based analysis}

In its general outlines, the analysis presented so far has been somewhat intuitive and pre-theoretical. We will now consider how the basic scenario that /r/ was originally, at the Proto-Japanese stage, a segment empty in feature content, resulting from the default filling of an empty onset slot in the intervocalic position, can be captured within the framework of Optimality Theory (Prince \& Smolensky, 1993/2004).

I assume that the phonological features of the Japanese consonantal system are the following: Voiced, Sonorant, Nasal, Continuant, Labial, Coronal, Dorsal. I also assume that place features such as [coronal], [labial], and [dorsal] are one-valued (privative), whereas laryngeal and class features such as [voiced], [sonorant], [continuant] and [nasal] are two-valued (binary), thus [+voiced] contrasts with [-voiced], and so on.

In order to account for the output forms containing a full consonant in place of zero at the stage of Proto-Japanese, I posit the following three sets of constraints: i) well-formedness constraints (which include faithfulness constraints as well as structural constraints); ii) featural agreement constraints; iii) harmony scale constraints. The first set includes the following four general and familiar constraints (Prince \& Smolensky 1993/2004, McCarthy and Prince 1993):

ONSET: prosodic units (= moras/syllables) should have an onset

Align(Stem, L, Prosodic Word, L): the left edge of the prosodic word coincides with

13 Other segments obeying distributional restrictions in OJ are the voiced obstruents /b/, /d/, /g/, and /z/. They do not appear word-initially, and are limited to one occurrence per stem. But contrary to $/ \mathrm{r} /$, these segments are commonly analyzed as heavily marked in the phonological system of Japanese (Komatsu 1981, Ito and Mester 2003, Labrune 2012). 
the left edge of the stem

MAXIO: input segments must have output correspondents (no deletion)

DEPIO: output segments must have input correspondents (no epenthesis)

The relative ranking of these four constraints is provided in (5).

$$
\text { ALIGN }>\text { ONSET, MAXIO > DEPIO }
$$

These constraints, and the proposed hierarchy, account for the fact that the zero consonant will be filled in but only outside of the word-initial position, as shown in tableau (6). Align(Stem, L, PrWd, L) prevents epenthesis in the initial position (see McCarthy and Prince 1993 for ) in order to keep the beginning of the output prosodic word identical to the input form, a principle which is grounded in the cognitive process of word-recognition and aims at facilitating it. As can be seen through the comparison between tableaux (6) and (7), there is no ranking argument for ONSET and MAXIO, SO we shall leave these two constraints unranked with respect to each other, in between ALIGN and DEPIO. DEPIO has to be the lowest-ranked constraint if we want to account for the fact that vowel-initial roots are never realized as consonant-initial.

(6)

\begin{tabular}{|c|l|l|l|l|}
\hline Input V V & ALIGN & ONSET & MAXIO & DEPIO \\
\hline a. V & & $*$ & $* !$ & \\
\hline b. VV & & $* * !$ & & \\
\hline c. CVCV & $* !$ & & & $* *$ \\
\hline d. VCV & & $*$ & & $*$ \\
\hline
\end{tabular}

(7)

\begin{tabular}{|c|l|l|l|l|}
\hline Input V V & ALIGN & MAXIO & ONSET & DEPIO \\
\hline a. V & & $* !$ & $*$ & \\
\hline b. VV & & & $* * !$ & \\
\hline c. CVCV & $* !$ & & & $* *$ \\
\hline d. VCV & & & $*$ & $*$ \\
\hline
\end{tabular}

Tableaux (6) and (7) show that candidate (d), i.e. VCV, is the optimal output.

The next subset of constraints will have to account for the feature content of the 
epenthetic $\mathrm{C}$ in VCV (candidate d), that is, which consonant exactly is inserted. This will be done by invoking two subgroups of markedness constraints: FEATURAL AgREEMENT and HARMONY SCALE.

FEATURAL AGREEMENT refers to a syntagmatic, contextual type of constraint prohibiting consecutive adjacent segments which do not share the same value for a given feature, hence *[? Feature] [-? Feature] (Baković 2000). This type of constraint basically encodes an assimilation process, or "sequential markedness" following the term used by Ito \& Mester (2003:181). FEATURAL AGREEMENT subsumes the following four individual constraints:

(8) FEATURAl AgreEMENT: * *?F][-?F]
a. *[?Sonorant][-?Sonorant]
b. *[? Voiced][-?Voiced]
c. *[?Nasal][-?Nasal]
d. *[?Continuant][-?Continuant]

Since there is no evidence for the relative sub-hierarchy of these four Featural Agreement constraints, we shall leave them unranked with respect to one another. The interaction of the featural agreement contraints given in (8) selects a non-nasal sonorant as the optimal output for a VCV sequence, as shown in tableau (9). This is because the medial C must share its features with the two surrounding vowels. So like OJ vowels, this consonant must be [+sonorant], [+voiced], [-nasal] and [+continuant]. ${ }^{14}$

We only consider here the most serious competitors to /r/ as an epenthetic segment, given what is generally assumed to have constituted the phonemic system of $\mathrm{OJ}$, and with the addition of a couple of other consonants such as $/ \mathrm{h} / \mathrm{and} / \mathrm{f} /$ which appear as potential rivals to /r/ as default epenthetic segments. ${ }^{15}$ Thus, for any given input consisting of a sequence of two identical or different vowels, fifteen serious

14 We suppose that $/ \mathrm{r} /$ is phonologically [+Continuant], because most of its modern phonetic realizations are, but this feature is actually not distinctive for $/ \mathrm{r} /$ in MJ (remember that /r/'s realizations are either [+Continuant] or [-Continuant], see 2.1). 15 Note that the consonant system of the language has not substantially changed over the past 1500 years, except for the development of $/ \mathrm{h} /$ out of $/ \mathrm{p} /$, and the phonemic split of $/ \mathrm{s} /, / \mathrm{z} /, / \mathrm{t} /$ and $/ \mathrm{d} /$ which gave rise to $/ \mathrm{s} /-/ \int /, / \mathrm{z} /-/ 3 /, / \mathrm{t} /-/ \mathrm{t} \int /$, and $/ \mathrm{d} /-/(\mathrm{d}) 3 /$. 
candidates can be considered. Tableau (10) shows that /r/, /w/ and /y/ are the optimal epenthetic segments to break up a VV sequence. (Since it only seeks to illustrate how the featural agreement constraints work to evaluate the segmentally optimal epenthetic consonant, no input is given.)

(9)

\begin{tabular}{|c|c|c|c|c|}
\hline & $*[\alpha \operatorname{Son}][-\alpha \operatorname{Son}]$ & $*[\alpha \operatorname{Voi}]\left[-\alpha V_{o i}\right]$ & $*[\alpha \mathrm{Nas}][-\alpha \mathrm{Nas}]$ & $*[\alpha \operatorname{Con} t][-\alpha \operatorname{Cont}]$ \\
\hline a. $\mathrm{VpV}$ & $*$ & $*$ & & $*$ \\
\hline b. $\mathrm{VbV}$ & $*$ & & & $*$ \\
\hline c. $\mathrm{VmV}$ & & & $*$ & $*$ \\
\hline $\mathrm{d} . \mathrm{VwV}$ & & & & \\
\hline e. $\mathrm{VtV}$ & $*$ & $*$ & & $*$ \\
\hline f. $V d V$ & $*$ & & & $*$ \\
\hline g. $\mathrm{VnV}$ & & & $*$ & $*$ \\
\hline $\mathrm{h} . \mathrm{VyV}$ & & & & \\
\hline i. $\mathrm{VrV}$ & & & & \\
\hline j. $\mathrm{VsV}$ & $*$ & $*$ & & \\
\hline k. VzV & $*$ & & & \\
\hline 1. $\mathrm{VkV}$ & $*$ & $*$ & & $*$ \\
\hline m. $\mathrm{VgV}$ & $*$ & & & $*$ \\
\hline n. VhV & $*$ & $*$ & & \\
\hline o. V?V & $*$ & $*$ & & $*$ \\
\hline
\end{tabular}

Tableau (9) shows that (i) $/ \mathrm{VrV} /$, (d) $/ \mathrm{VwV} /$ and (h) $/ \mathrm{VyV} /$ are the three optimal candidates because all three display an epenthetic consonant which shares the features 
[+Sonorant], [+Voiced], [-Nasal], and [+Continuant] with the surrounding vowels.

Finally, the last subset of segmental markedness constraints, the universal harmony scale constraints, will select the form with /r/ as the best output candidate. The universal harmony scale, originally proposed by Prince \& Smolensky (1993: 180 $s q / 2004)$, results from the relative ranking of a set of three featural markedness constraints, as shown in (10).

HARMONY SCALE:

*Pl/DoRsal, *PL/LABIAL $>$ *PL/CORONAL

These constraints state that segments with a dorsal or labial place of articulation (Pl/Dorsal, Pl/LABIAL) are more marked than coronals (Pl/CORONAL). *Pl/CORONAL being ranked lower in the harmony scale hierarchy than *PL/DORSAL and *PL/LABIAL, the segments /w/ and /y/ which are not coronal will be penalized. ${ }^{16}$ The candidate containing the coronal epenthetic consonant /r/ will emerge as the optimal output, as shown in (11). Candidates (d) and (h) $/ \mathrm{VwV} /$ and $/ \mathrm{VyV} /$ thus lose over $/ \mathrm{VrV} /$.

$16 / y /$ is categorized as a dorsal segment. Dorsal segments involve a constriction formed by the body of the tongue, thus including dorso-palatal segments such as $/ y /$, while coronal corresponds to alveolar and apical segments. I assume that Japanese /y/ (IPA j) is a palatal and not a coronal, because it is neither apical nor laminal, contrary to coronals such as /t, d, s, z, r/. Following Clements \& Hume (1995:286), I consider that palatality is characterized in terms of a [-back] dorsal feature. Consequently, /y/ has to be characterized as a dorsal, [-back] consonant.

It is interesting to observe that candidate (11c) /aya/, with intervocalic /y/, appears to be the second best candidate after /ara/. Empirical evidence confirms this relative harmony of $/ y /$, as sporadic alternation between $/ \mathrm{r} /$ and $/ \mathrm{y} /$ is attested in OJ. It seems to occur especially at the beginning of certain suffixes, for instance in -ra-ru / -ra-yu (OJ) 'passive auxiliary', -raka / -yaka 'adjectival suffix' (name-raka "smooth", vs. nigi-yaka "cheery"). The existence of such an alternation, which seems to be frequent in the environment of a high vowel, probably results from the assimilation of some feature of the adjacent high vowel onto the intervocalic slot. 


\begin{tabular}{|c|c|c|c|}
\hline & $* \mathrm{Pl} /$ Dorsal & $* \mathrm{Pl} /$ Labial & $* \mathrm{P} \mathrm{l} /$ Coronal \\
\hline a. $\mathrm{VrV}$ & & & $*$ \\
\hline b. $\mathrm{VwV}$ & $* !$ & $*$ & \\
\hline c. $\mathrm{VyV}$ & $* !$ & & \\
\hline
\end{tabular}

Let us now examine how the three subsets of constraints interact with each other in order to produce the correct output $\mathrm{VrV}$. The general ranking is provided in (12):

(12) Constraint hierarchy:

\section{Align $\gg$ ONSET, MAXIO $\gg$ DEPIO $>$ FEATURAL AGREEMENT $\gg$ HARMONY SCALE}

HARMONY SCALE constraints have to be ranked below the FEATURAL AGREEMENT constraints, otherwise the emerging default consonant would be a segment with no supra-laryngeal place of articulation, such as /h/ or / $/$ / which are assumed to be [sonorant]. The first group of constraints, the well-formedness constraints, are ranked above the featural agreement constraints and the harmony scale constraints because otherwise, a candidate with either an initial epenthetic consonant $(/ \mathrm{rVrV} /)$ or no intervocalic epenthetic consonant $(/ \mathrm{VV} /)^{17}$ would emerge as optimal.

Notice that none of the constraints invoked here are language specific. They are all very general constraints, based on widely recognized, theory-independent phonological principles.

Tableau (13) below illustrates how /r/ is indeed the most harmonic output for zero, given the constraints and the hierarchy proposed above. In order to keep the tableau to reasonable size, we will adopt the following conventions. Violations to FEATURAL AGREEMENT will be marked by indicating which feature(s) cause(s) a violation in the FEATURAL AGREEMENT column. The presence of a feature in the column is thus

17 Contrary to MJ, OJ had no long vowels (Martin 1987:45). Long vowels developed long after the phonemic emergence of $/ \mathrm{r} /$, that is around year 1000, under the influence of Chinese loans in Japanese and intervocalic consonant lenition, so there is no need to introduce a specific constraint which would rule out /r/ insertion between two identical vowels in order to allow long vowels to be faithfully preserved at the surface. 
equivalent to the presence of $\mathrm{a}^{*}$, and a blank indicates that no violation occurs.

(13)

\begin{tabular}{|c|c|c|c|c|c|c|c|c|}
\hline Input: VV & ALIGN & ONSET & MAXIO & DEPIO & FEAT-AGR & \multicolumn{3}{|c|}{ HARMONY SCALE } \\
\hline a. V & & $*$ & $* !$ & & & & & \\
\hline b. VV & & $* * !$ & & & & & & \\
\hline c. $\mathrm{rVrV}$ & $* !$ & & & $* *$ & & & & $* *$ \\
\hline $\mathrm{d} . \mathrm{VrV}$ & & $*$ & & $*$ & & & & $*$ \\
\hline e. VwV & & $*$ & & $*$ & & $* !$ & $*$ & \\
\hline f. VyV & & $*$ & & $*$ & & $* !$ & & \\
\hline g. VdV & & $*$ & & $*$ & Son! Cont & & & $*$ \\
\hline h. VtV & & * & & $*$ & Son! Ved Cont & & & * \\
\hline i. $\mathrm{VnV}$ & & * & & * & Nas! Cont & & & * \\
\hline j. VsV & & * & & $*$ & Son! Vcd & & & $*$ \\
\hline k. VzV & & $*$ & & $*$ & Son! & & & $*$ \\
\hline 1. $\mathrm{VpV}$ & & $*$ & & $*$ & Son! Ved Cont & & $*$ & \\
\hline m. $\mathrm{VbV}$ & & $*$ & & $*$ & Son! Cont & & $*$ & \\
\hline n. $\mathrm{VmV}$ & & $*$ & & $*$ & Nas! Cont & & $*$ & \\
\hline o. VkV & & $*$ & & $*$ & Son! Ved Cont & $*$ & & \\
\hline p. $\mathrm{VgV}$ & & $*$ & & $*$ & Son! Cont & $*$ & & \\
\hline q. VhV & & $*$ & & $*$ & Son! Vcd & & & \\
\hline r. VPV & & $*$ & & $*$ & Son! Ved Cont & & & \\
\hline
\end{tabular}

Candidates (c), (b) and (a) are eliminated straight away because contrary to the 
rest of the candidates, they display, respectively, one fatal infraction to ALIGN, two fatal infractions to ONSET and one fatal infraction to MAX. All other candidates, from (d) to (r), score identically with respect to these three top constraints: they all incur one violation to ONSET and one to DEP. Looking at the next constraint set, FEATURE AGREEMENT, we can verify that only three candidates satisfy the featural agreement requirements: (d) $/ \mathrm{VrV} /$, (e) $/ \mathrm{VwV} /$ and (f) $/ \mathrm{VyV} /$.

If we now consider the HARMONY SCALE constraints, we see that candidates (d) $/ \mathrm{VrV} /$ is the optimal output. Notice that /h/ and / $/$ / (candidates $\mathrm{q}$ and $\mathrm{r}$ ) would be better candidates than $/ \mathrm{r} /$ insofar as they do not have a place of articulation. However, they violate the FEATURAL AGREEMENT constraints, and therefore lose over /r/. Candidate (d) / VrV/ thus appears as the optimal output for the input /VV/.

In the light of the present analysis, the process underlying the emergence of $/ \mathrm{r} /$ in Proto-Japanese can be seen as an instance of "The Emergence of The Unmarked", in the sense of McCarthy \& Prince (1994).

\subsection{Lexicon optimization and /r/ phonologization}

The analysis proposed here is that $\mathrm{MJ} / \mathrm{r} /$ is the result of a two-step diachronic process which occurred at the Proto-Japanese period. Step 1 corresponds to a stage where zero in the input is mapped to $[\mathrm{r}]$ in the output, according to the constraint hierarchy shown above. At step 2, zero in the input has been lost and replaced by /r/, by virtue of Lexicon Optimization (Prince \& Smolensky, 1993: 192, Kager, 1999:32). New learners, who never hear [VV], have come to identify / $\mathrm{VrV} /$ as the underlying form for surface $[\mathrm{VrV}]$ because $/ \mathrm{VrV} /$ incurs the fewest violations to faithfulness, causing /r/ to be added as a new segment in the phonological inventory of Proto-Japanese. In other words, what we have at this stage is a phonologization process.

My claim is that the properties which are exhibited by $\mathrm{MJ} / \mathrm{r} /$ result from the conditions of its emergence in the language. ${ }^{18}$ That is, modern /r/ has retained something

18 An alternative account of the distributional asymmetries of $/ \mathrm{r} /$ could be considered : one could suppose that $/ \mathrm{r} /$ is present underlyingly, but that it is deleted word-initially, due to the action of a constraint banning liquids from the initial position. Such a constraint is actually posited by Ueda \& Davis (2001), in an attempt to provide an account of the acquisition of /r/ in Japanese. However, Ueda and Davis (2001) were 
of its "ancestor" zero, as can be inferred from its status and behavior in present-day Japanese.

\section{Conclusion and further issues}

This study has been an attempt to provide a principled account of the many particularities of $/ \mathrm{r} /$ in Japanese from a panchronic perspective. The purpose is to understand how /r/ emerged and developed in Proto-Japanese, and how the conditions of its emergence can shed light on its present phonological behavior.

First, a description of the phonetic, phonological and morpho-phonological characteristics of /r/ in Japanese has been presented, through examination of a large array of empirical evidence. The picture that emerges is that of an unmarked, phonologically empty segment. Second, we have proposed a formal account for the emergence of $/ r /$ in Proto-Japanese within the framework of Optimality Theory. The basic idea is that /r/ was originally a segment empty in feature content at the input level. We have argued that the phonological content of $/ r /$ is acquired due to the application of well-formedness constraints such as ONSET and ALIGN, as well as two sets of markedness constraints, FEATURAL AGREEMENT and HARMONY SCALE, which ensure that the empty input is mapped to the least marked output in terms of phonological features. $/ \mathrm{r} /$ should therefore be interpreted as the intervocalic default realization of zero at the stage of Proto-Japanese, before becoming a fully contrastive phoneme later on by virtue of a process of phonologization.

This study also has important typological implications, and a number of issues deserve further study and analysis. Strikingly enough, some of the particularities which have been encountered with Japanese /r/ can be found in a number of other languages of

concerned with the synchronic analysis of Japanese phonology with respect to /r/ being a late acquired segment. They do not address the diachronic issue in their paper.

The r-deletion approach would fail to explain why $/ \mathrm{r} /$ is overwhelmingly frequent in the Japanese language, especially at the beginning of bound morphemes, whereas our analysis is able to relate $/ \mathrm{r} / \mathrm{s}$ frequency with that of $/ \%$. The deletion approach is also incapable of accounting for the fact that liquids are allowed at the beginning of foreign loans, including the first Chinese borrowings between the $4^{\text {th }}$ and $6^{\text {th }}$ centuries. Finally, if one considers that $/ r /$ is simply deleted word initially, one can no longer account in a unified manner for its phonological inertness, and for all the other properties presented in section 2 . 
the world. I was able to collect a list of more than 120 languages which, like Old Japanese, ban the occurrence of a liquid, typically a $r$-sound, in the initial position of native independent words (Labrune, in preparation). It is particularly intriguing to note that several proto-languages including Proto-Altaic, Proto-Indo-European, ProtoAustronesian, Proto-Dravidian and Proto-Australian, as well as languages isolates such as Basque or Burushaski, lack /r/ in word-initial position. This might suggest that $/ \mathrm{r} /$ could have developed relatively late in some languages inventories, following a scenario closely resembling the one posited for Japanese; but this is only a tentative hypothesis that deserves further attention in future research. But whatever its causes, word-initial prohibition should definitely be added to the set of properties characterizing the rhotics from a general linguistic point of view, because it figures among the most recurring properties of these consonants cross-linguistically.

In parallel to distributional asymmetries, another characteristic which we observed in Japanese, namely /r/'s outstanding frequency, is also well attested cross-linguistically. In a rather significant number of languages, the rhotic is the most frequent (French, Portuguese, Korean, Susu, Unya, etc.), or among the most frequent (English, Spanish, Latin, Italian, German, Mandingue, etc.) of all consonants (Wioland 1991, Zipf and Rogers 1939, Yu 1985, Houis 1963, Rivierre 1973, Hayden 1950, Delafosse 1955).

The complementary distribution between / $\mathrm{r}$ / and zero is also an issue which should deserve more careful examination, since it seems to occur in a number of languages outside of Japanese. ${ }^{19}$ In addition, Japanese is far from being the only language which favors /r/ as a default epenthetic consonant. Similar cases of liquid insertion seem to occur in a number of other languages. Rhotics probably serve more often as epenthetic consonants resulting from a default filling process than is commonly assumed by phonologists. This issue is still underdocumented, but Labrune $(1997,1998)$ and Uffmann (2007), for instance, make the strong claim that /r/ is not only a possible, but

19 Van Oostendorp (2001: 115) mentions the fact that in Groningen Dutch, “/r/ alternates between [r] and zero, because of its placelessness". He also cites Humbert (1996), for whom " $/ \mathrm{r} /[\ldots]$ has a relatively unspecified vowel-like structure which could be filled in by the environment". Giegerich (1999) writes that "in English non-rhotic dialects there is an empty segment /0/ which is realized as [ə] before consonant or pause, or as [r] before a vowel. For Giegerich, in English, "[r] and zero are surface realizations, in complementary distribution, of the same melodic underlier". 
also an optimal default epenthetic consonant because of its phonological nature. Uffmann reports a number of cases of zero-liquid alternations which, he claims, could be viewed as liquid insertion. He argues that /r/ can be a natural hiatus breaker in languages, and proposes a detailed account of English intrusive /r/ along this line of analysis.

Much investigation thus remains to be done regarding the peculiar nature of liquids and particularly rhotics from a typological point of view. It is important to document the issues mentioned above more thoroughly in the future and to consider the reasons why such similar patterns of rhotic distribution, frequency, and relationship with zero frequently occur across languages. ${ }^{20}$ An open question is whether an analysis similar to the one developed in this paper in order to account for the distributional asymmetries of $/ r /$ in Japanese might be extended to other languages.

\section{Acknowledgements:}

I wish to thank Komatsu Hideo, Kitahara Yasuo, Hayashi Chikafumi, the late Haraguchi Shosuke, Jôo Hakutarô and Takayama Tomoaki at the University of Tsukuba, as well as Irène Tamba at the EHESS in Paris for thought-provoking discussions and many useful comments on several aspects of the materials discussed here many many years ago. Special thanks go to Mark Irwin for reading and commenting on a recent version of this article. I am also very grateful to two anonymous reviewers and to the editors of the Journal of East Asian Linguistics for their helpful comments and suggestions. A previous version of this paper was presented at the second "r-atics" conference in Brussels. I express my gratitude to the organizers and participants there for additional comments.

\section{REFERENCES}

Baković, Eric. 2000. Harmony, Dominance and Control. Phd thesis. New Brunswick, NJ: Department of Linguistics, Rutgers University.

20 The studies by Lindau (1985), Walsh-Dickey (1997), Wiese (2001), Proctor (2009), and the collection of papers in van Hout \& van de Velde (2001) provide interesting facts and analyzes concerning the nature, structure and characterization of liquids across languages or within individual languages. 
Beckman, Jill N. 1999. Positional Faithfulness: An Optimality Theoretic Treatment of Phonological Asymmetries [Outstanding Dissertations in Linguistics]. New York and London: Garland.

Clements, Nick \& Hume, Elisabeth. 1995. The internal organization of speech sounds, in The Handbook of Phonological Theory, Goldsmith, John (ed): 245-306. Cambridge: Cambridge University Press.

De Chene, Brent. 1985. R-epenthesis and the Japanese verb. Papers in Japanese Linguistics 10: 170-207.

Delafosse, Maurice. 1955. La langue mandingue et ses dialectes (2 vol.). Paris: Paul Geuthner.

Frellesvig, Bjarke. 2008. On reconstruction of Proto-Japanese and Pre-Old Japanese verb inflection, in Proto-Japanese, issues and prospects (Current issues in Linguistic Theory 294), Frellesvig, Bjarke and Whitman, John (eds): 175-192. Amsterdam: John Benjamins.

Fujioka, Katsuji. 1908. Nihongo no chii. Kokugakuin Zasshi 14.

Giegerich, Heinz J. 1999. Lexical Strata in English. Cambridge: Cambridge Un. Press.

Greenberg, Joseph H. 1966. Language Universals. The Hague: Mouton.

Hamano, Shoko. 1998 (first pub. 1986). The Sound Symbolic System of Japanese. Tokyo: Kuroshio.

Hattori, Shirô. 1960. Gengogaku no hôhô. Tokyo: Iwanami.

Hayden, R. 1950. The relative frequency of phonemes in General American English. Word 6-3: 217-223.

Houis, Maurice. 1963. Etude descriptive de la langue susu (Mémoires de l'Institut Français d'Afrique Noire). Dakar: IFAN.

Humbert, Helga. 1996. De Kameleontische aard van de Groningse /r/ verklaard vanuit representationeel perspectief. Taal en Tongval 48 (2): 139-162.

Irie, Sayaka. 1996. Gendai Nihongo ni okeru wago sanhaku meishi ni tsuite. Dôshisha Kokubungaku 43:97-108.

Ito, Junko and Mester, Armin. 1995. Japanese phonology. in The Handbook of Phonological Theory, Goldsmith, John (ed): 817-838. Cambridge: Cambridge University Press.

Ito, Junko and Mester, Armin. 1999. The phonological lexicon, in The Handbook of 
Japanese Linguistics, Tsujimura, Natsuko (ed). Oxford: Blackwell. 62-100.

Ito, Junko and Mester, Armin. 2003. Japanese Morphophonemics. Markedness and Word Structure. (Linguistic Inquiry Monograph 41). Cambridge (MA): The MIT Press.

Kager, René. 1999. Optimality Theory. Cambridge: Cambridge University Press.

Kawahara, Shigeto, Ono, Hajime and Sudo, Kiyoshi. 2006. Consonant cooccurrence restrictions in Yamato Japanese. In Japanese / Korean Linguistics 14, Vance, Timothy and Jones, Kimberly (eds.) . CSLI Publications: Stanford. 27-38.

Kishida, Takeo. 1984. Kokugo on'in henka no kenkyû. Tokyo: Musashino Shoin.

Kokuritsu Kokugo Kenkyûjo [National Center for Research on the Japanese Language]. 1984. Nihongo no Goi to Kyôiku. Tokyo: Kokuritsu Kokugo Kenkyûjo Publications.

Komatsu, Hideo. 1981. Nihongo no on'in (Nihongo no sekai $n^{\circ}$ 7). Tokyo: Chûô Kôronsha.

Kuginuki, Tooru. 1982. Jôdai Nihongo ra-gyôon-kô. Toyama Daigaku Jinbungakubu Kiyô 6 : 192-206.

Kurematsu, Akira. 1997. Intsu jôhô no jôhô kagaku he no tekiyô. In Nihongo Onsei (2), akusento, intonêshon, rizumu to pôzu, Sugito, Miyoko (ed), 303-318. Tokyo: Sanseidô.

Kurisu, Kazutaka. 2009. Palatalisability via feature compatibility. Ph 26-3. 437-475.

Labrune, Laurence. 1996. La formation des désinences verbales en japonais ancien. Cipango 5 : 141-171.

Labrune, Laurence. 1997. Inertie phonologique, absence de marque et sousspécification : la consonne $r$ en japonais. In Absence de Marque et Représentation de l’Absence. Deléchelle, Gérard and Fryd, Marc (eds). 245-267. Travaux Linguistiques du Cerlico 10, Presses Universitaires de Rennes : Rennes.

Labrune, Laurence. 1998. De l'iconicité en japonais: suffixes en $r+$ voyelle et réduplication. Cahiers de Linguistique Asie Orientale 27(1) : 79-118.

Labrune, Laurence. 2012. The Phonology of Japanese (The Phonology of the World's Languages). Oxford University Press: Oxford and New York.

Labrune, Laurence. in preparation. Word-initial liquid prohibition: a typological survey. Ms.

Lawrence, Wayne. 2000. Shiin wo koete okoru boin no yûgô - Ryûkyû hôgen ni okeru 
genshô wo chûshin ni. Onsei Kenkyû (Journal of the Phonetic Society of Japan) 4 (1): $55-60$.

Lindau, Mona. 1985. The Story of /r/. In Phonetic Linguistics, Essays in Honor of Peter Ladefoged, Fromkin, Victoria (ed), 157-168. Orlando: Academic Press.

Maddieson, Ian. 1984. Patterns of Sounds. Cambridge: Cambridge University Press.

Martin, Samuel. 1987. The Japanese Language through Time. New Haven and London: Yale University Press.

Matsuno, Kazuhiko. 1971. Some allophones of Japanese $/ \mathrm{r} /$ and their stylistic values. Onseigakkai Kaihô 136: 5-8.

McCarthy, John and Prince, Alan. 1993. Generalized alignment. Yearbook of Morphology: 79-153. Dordrecht: Kluwer.

McCarthy, John and Prince, Alan. 1994. The emergence of the unmarked: Optimality in Prosodic Morphology. Proceedings of the North East Linguistic Society. Amherst: GLSA: 333-379.

McCarthy, John and Prince, Alan. 1995. Faithfulness and reduplicative identity. In University of Massachussets Occasional Papers in Linguistics 18, Beckman, Jill et al. (ed), 318-366. Amherst: GLSA.

McCawley, James. 1968. The phonological Component of a Grammar of Japanese. The Hague: Mouton.

Mester, Armin and Ito, Junko. 1989. Feature predictability and underspecification: palatal prosody in Japanese mimetics. $L g$ 65: 258-293.

Miyake, Marc Hideo. 2003. Old Japanese: a Phonetic Reconstruction. Routledge Curzon: London and New York.

Nasukawa, Kuniya and Backley, Phillip. 2011. The internal structure of ' $r$ ' in Japanese. Onsei Kenkŷ̂ / Phonological Studies 14 (The Phonological Society of Japan). 27-34.

Ohnishi, Masayuki. 1987. Dôteki jinkô kôgai ni yoru nihongo shiin no kôsatsu. Onsei Gakkai Kaihô 186: 19-24.

Ohno, Susumu. 1953. Nihongo no dôshi no katsuyôkei no kigen ni tsuite. Kokugo to Kokubungaku 30-6: 47-56.

Paradis, Carole and Prunet, Jean-François. (eds). 1991. The special Status of Coronals: internal and external evidence. San Diego: Academic Press.

Prince, Alan and Smolensky, Paul. 1993/2004. Optimality Theory: Constraint 
Interaction in Generative Grammar. Technical report, Rutgers University \& University of Colorado at Boulder, 1993. Revised version published by Blackwell, 2004.

Proctor, Michael Ian. 2009. Gestural Characterization of a Phonological Class: the Liquids. Phd dissertation. Yale University.

Rivierre, Jean-Claude. 1973. Phonologie comparée des dialectes de l'extrême sud de la Nouvelle Calédonie. Paris: Selaf.

Sagisaka, Yoshinori and Tohkura Yoh'ichi. 1984. Phoneme duration control for speech synthesis by rule. Transactions of the IECE J67-A. 629-636.

Sakakura, Atsuyoshi. 1966. Gokôsei no Kenkyû. Tokyo: Kadokawa.

Schourup, Lawrence and Tamori, Ikuhiro. 1992. Japanese palatalization in relation to theories of restricted underspecification. Gengo Kenkŷ̂ 101:107-145.

Tsuzuki, Masaki and Lee, Hyun-Bok. 1992. A phonetic study of the Korean and Japanese lateral, flap and nasal. In Proceedings of the 1992 Seoul International Conference on Linguistics, the Linguistic Society of Korea (ed), 761-780. Seoul: Koryo university.

Ueda, Isao and Davis, Stuart. 2001. The acquisition of Japanese r. Gengo Kenkŷ̂ 119: 111-139.

Uffmann, Christian. 2007. Intrusive [r] and optimal epenthetic consonants. Language Sciences 29: 451-476.

Unger, James M.. 1977. Studies in Early Japanese Morphophonemics. Phd thesis. Yale University.

van Hout, Roeland and Van de Velde, Hans. 2001. Patterns of /r/ variation, In r-atics, Sociolinguistics, Phonetic and Phonological characteristics of /r/, van Hout, Roeland $\&$ Van de Velde, Hans (eds), [Etudes et Travaux n 4],1-9.

van Oostendorp, Marc. 2001. The phonology of postvocalic /r/ in Brabant Dutch and Limburg Dutch, In r-atics, Sociolinguistics, Phonetic and Phonological characteristics of /r/, van Hout, Roeland \& Van de Velde, Hans (eds), 113-122.

Walsh Dickey, Laura. 1997. The Phonology of Liquids. Phd thesis. Amherst: University of Massachussets.

Wenck, Günther. 1966. The Phonemics of Japanese, Questions and Attempts. Wiesbaden: Otto Harrassowitz. 
Whitman, John. 2008. The source of the bigrade conjugation and stem shape in Pre-Old Japanese. Proto-Japanese, Issues and Prospects (Currents issues in Linguistic Theory 294), Frellesvig, Bjarke and Whitman, John (eds): 159-173. Amsterdam: John Benjamins.

Wiese, Richard. 2001. The unity and variation of German /r/. In r-atics, Sociolinguistics, Phonetic and Phonological characteristics of /rl, van Hout, Roeland \& Van de Velde, Hans (eds) [Etudes et Travaux 4], 11-26.

Wioland, François. 1991. Les sons du français. Paris: Hachette.

Yamaguchi, Yoshinori. 1985. Kodai Nihongo Bunpô no Seiritsu no Kenkŷ̂. Tokyo: Yûseidô.

Yoshida, Kanehiko. 1976. Nihongo Gogengaku no Hôhô. Tokyo: Taishûkan.

Yu, Chae-Weon. 1985. Uri mal yeoksun sajeon. Seoul: Jeongeumsa.

Zipf, George Kinsley and Rogers, Francis Millet. 1939. Phonemes and variphones in four present-day romance languages and classical Latin from the point of view of dynamic philology. Archives Néerlandaises de Phonétique Expérimentale 15: 111147. 